\title{
THE EFFECT OF INCREASED INTRA-ABDOMINAL PRESSURE ON RENAL FUNCTION IN MAN ${ }^{1}$
}

\author{
BY STANLEY E. BRADLEY AND GERALDINE P. BRADLEY \\ (From the Robert Dawson Evans Memorial, Massachusetts Memorial Hospitals, and the De- \\ partment of Medicine, Boston University School of Medicine)
}

(Received for publication March 26, 1947)

It is well established that increased intra-abdominal pressure alters renal function. In experimental animals, distention of the abdominal cavity under pressures greater than $15 \mathrm{~mm}$. of mercury usually reduces urine flow and, under pressures greater than $30 \mathrm{~mm}$., stops urine flow altogether (1). In man, a tense accumulation of ascitic fluid may be associated with oliguria and the retention of water and salt, which disappear following paracentesis (1). In one respect, increased intra-abdominal pressure seems to improve the function of the kidney, for the urine may become highly concentrated during the period of oliguria. This effect has found practical application in the hands of radiologists $(2,3)$, who use abdominal compression during intravenous pyelography to assure maximum density of the contrast media excreted by the kidneys.

Until the present there has been no satisfactory explanation for these alterations in renal function during abdominal pressurization. It has been suggested that they are due to partial urinary obstruction (3), but the radiologic evidence is against this explanation (4). Urine flow may be increased by diuretics during the application of pressure in experimental animals, indicating the absence of obstruction. Thorington and Schmidt (1) have called attention to the possibility that the associated increased renal venous pressure may interfere with normal blood flow through the kidney and disturb renal function.

Recently, abdominal compression has been used as a means of protecting airmen against the illeffects of centrifugal force (positive G) (5). It was assumed that pressurization prevents the pooling of venous blood in the abdominal veins and sustains the return of blood to the heart. The

1 This work was done under a contract, recommended by the Committee on Medical Research, between the Office of Scientific Research and Development and the Massachusetts Memorial Hospitals. present study, undertaken primarily to determine whether such procedures have detrimental effects on the abdominal organs (6), revealed that the diversion of arterial blood from large visceral circuits to more vital regions, such as the brain, is also an important factor.

\section{METHODS}

The clearance and saturation methods devised by Smith and his coworkers ( 7 to 9 ) were used to evaluate renal hemodynamics and tubular activity during abdominal compression in 17 normal human subjects, ranging in age from 17 to 50, almost equally divided as to sex, and clinically free of cardiovascular and renal disease. The effective renal plasma flow was measured by the diodrast or p-aminohippurate (PAH) clearances; and the glomerular filtration rate, by the mannitol or inulin clearances. ${ }^{2}$ The maximal rate of tubular glucose reabsorption (glucose $\mathrm{Tm}$ ) and the maximal tubular diodrast excretory rate (diodrast $\mathrm{Tm}$ ) were determined to estimate tubular function and to assess the distribution of filtrate and perfusate to tubular tissue.

The pressure within the abdomen was increased by inflating a rubber bladder with air under pressure, beneath a girdle tightly applied to the abdomen. The bladder, sewn into a pocket in the girdle, covered the anterior abdominal wall. Pressures between 70 and $80 \mathrm{~mm}$. $\mathrm{Hg}$ were applied during the determination of clearance and Tm values. These pressures were usually endured by the subject without complaint. Occasionally, however, slightly lower pressures were required or the period of application was shortened because of discomfort and respiratory difficulty. Among the subjects of the studies reported here, only very slight changes in blood pressure were observed during pressurization.

All subjects were examined in the basal fasting state, resting quietly in bed. Following the establishment of appropriate plasma levels of the test substances by a

2 A supply of sterile solutions of sodium p-aminohippurate (20 per cent) and mannitol (25 per cent) was made available for use in this study through the courtesy of the Medical Research Division of Sharpe and Dohme, Incorporated, Philadelphia, Pennsylvania. Diodrast was obtained in sterile solution (35 per cent) from the Winthrop Chemical Company, New York City; and inulin (10 per cent) from William R. Warner and Company, New York City. 
technique described at length elsewhere (7), the bladder was catheterized and washed out with a measured volume of isotonic saline solution. Urine was then collected by catheter at intervals of 10 to 15 minutes and carefully measured. After 2 or more control periods had been obtained, abdominal compression was continuously applied for 10 to 45 minutes and 1 to 3 collections of urine were made during this time. On most occasions, 2 or more urine-periods were obtained after the pressure was released. Samples of venous or arterial blood were taken at 30-minute intervals.

Diodrast, PAH, mannitol, and inulin were determined in cadmium filtrates of plasma (10) and in dilute samples of urine, using methods described by Goldring and Chasis (8). Glucose was determined by the NelsonSomogyi method (11) in cadmium filtrates of plasma and diluted urine. Clearance and $\mathrm{Tm}$ values were calculated by the procedures of Smith $(7,8)$.

In another group, comprising 15 subjects, a catheter was placed in the renal vein and venous pressures measured during the application of increased abdominal pressure. An extension of the technique developed by Cournand and Ranges (12) for the catheterization of the right atrium was employed. A small incision was made over a median basilic vein under local anesthesia and the vein secured by a suspensory ligature. A small longitudinal incision was then made in the vein with a bayonet scalpel, and an extra-length ureteral catheter ${ }^{3}$ with a curved tip (Cournand tip) was introduced into the lumen of the vein. Sterile isotonic saline solution flowed constantly through the catheter at a slow rate throughout the procedure to prevent blockage by clotting. The catheter was next passed into the superior mediastinum under fluoroscopic control and then into the chamber of the right atrium. The orifice of the inferior vena cava was entered with difficulty on many occasions, apparently owing to obstruction by the valve of the inferior vena cava. This obstruction could be passed by rotating the tip of the catheter to the right and posteriorly during passage through the atrium. In the inferior vena cava, the tip was directed to the right and usually passed with little difficulty into the right renal vein. The catheter tip could be localized far out to the right side of the abdominal cavity below the shadow of the liver. The left renal vein was catheterized less frequently and with somewhat greater difficulty. Pressure determinations were made in the renal vein and in the upper portion of the inferior vena cava with a saline manometer after the method of Moritz and von Tabora (13).

In 8 subjects, catheterization of the right renal vein was carried out for the determination of the percentage extraction of PAH by the kidney during abdominal pressurization. In this procedure, a constant plasma level of PAH ( 1 to $2 \mathrm{mgm}$. per cent) was established. Sam-

3 The catheters used in this study were manufactured by the United States Catheter and Instrument Corporation, Glens Falls, New York. They are 100 centimeters long and terminate in a curved tip (Cournand tip) with 1 eye. ples of blood were obtained simultaneously from the right renal vein and from a peripheral vein in the arm opposite to that in which the infusion was administered. The extraction percentage was calculated by dividing the difference between the concentration of PAH in the peripheral and renal venous blood by its concentration in the peripheral blood. This value, the percentage of PAH removed from each milliliter of blood as it traverses the kidney, was determined before, during, and following application of abdominal presssure.

\section{RESULTS}

\section{A. Alterations in renal blood flow and glomerular filtration during abdominal compression}

\section{Intra-abdominal pressure and renal venous pressure}

When the rubber bladder of the abdominal pressure cuff was inflated with air at pressures between 70 and $80 \mathrm{~mm} . \mathrm{Hg}$, it was found that intraabdominal pressure measured at various locations within the abdomen averaged $20 \mathrm{~mm}$. $\mathrm{Hg}$, within a very small range. This value was determined with a saline or Hamilton manometer in the stomach, duodenum, and rectum by means of the MillerAbbott tube (6), and in the bladder and renal pelvis by catheters. Such a uniform elevation of pressure throughout the confines of the abdomen provided evidence in support of the view that the abdomen and its contents could be considered as relatively non-compressible and fluid in character, behaving in accordance with Pascal's law. The difference in pressure between the cuff and the peritoneal cavity probably resulted from the resistance to compression by the abdominal wall and from the resistance to extension of pressure by the diaphragm.

The pressure in the cuff represented, therefore, the average force exerted upon the anterior abdominal wall, and did not necessarily reflect the pressure within the abdominal cavity. As a matter of fact, the intra-abdominal pressure varied considerably depending upon the state of contraction of the abdominal musculature. Thus, the average figure of $20 \mathrm{~mm}$. $\mathrm{Hg}$ was typical of complete relaxation, whereas pressures as high as $176 \mathrm{~mm} . \mathrm{Hg}$ (Table I) were recorded from the renal vein during a strong "bearing down" contraction of abdominal muscles. Contrariwise, increased rigidity of the abdominal wall, in pushing away the inflated bladder, blocked altogether the transmission of 
TABLE I

Intra-abdominal venous pressure before, during, and after abdominal compression

Pressure applied to anterior abdominal wall by pneumatic girdle at $80 \mathrm{~mm}$. $\mathrm{Hg}$. Venous pressure was measured with a saline manometer before, during, and after (recovery) the application of pressure. The pressures tabulated under "Strain" were obtained when the subject voluntarily increased his intra-abdominal pressure by a "bearing-down" maneuver, during the application of pressure.

\begin{tabular}{|c|c|c|c|c|}
\hline \multicolumn{5}{|c|}{ Renal vein } \\
\hline Subject & Control & $\begin{array}{l}\text { Abdominal } \\
\text { compression }\end{array}$ & Strain & Recovery \\
\hline $\begin{array}{l}\text { C. M. } \\
\text { R.S. } \\
\text { J.S. } \\
\text { W. C. } \\
\text { D. C. } \\
\text { O. C. } \\
\text { J. F. } \\
\text { H. B. } \\
\text { M. B. }\end{array}$ & $\begin{array}{c}\boldsymbol{m m} . \mathrm{Hg} \\
5.8 \\
6.4 \\
6.2 \\
7.9 \\
7.0 \\
5.3 \\
5.1 \\
2.9 \\
5.8\end{array}$ & $\begin{array}{c}m m . H g \\
18.1 \\
20.2 \\
17.6 \\
20.2 \\
22.1 \\
14.1 \\
18.9 \\
17.8 \\
16.0\end{array}$ & $\begin{array}{c}m m . H g \\
42.6 \\
45.8 \\
75.6 \\
88.1 \\
108.0 \\
\overline{176.0} \\
\overline{101.0}\end{array}$ & $\begin{array}{c}m m . \mathrm{Hg} \\
5.8 \\
9.6 \\
\overline{-} \\
\overline{5.7} \\
= \\
\overline{8.2}\end{array}$ \\
\hline
\end{tabular}

Inferior vena cava

\begin{tabular}{l|l|l|l|l}
\hline C. W. & 5.2 & 13.6 & 44.1 & - \\
O.C. & 2.4 & 24.5 & 38.1 & - \\
\hline
\end{tabular}

cuff pressure into the abdominal cavity. In certain well-muscled individuals (J. Q., Table II) the absence of renal functional change during $a b-$ dominal compression was ascribed to this factor.

Owing to the technical difficulties involved in measuring and maintaining constant intra-abdominal pressures, a constant compressional pressure was used during these studies, with the assumption that the averaged results could be discussed in terms of an average intra-abdominal pressure of 20 $\mathrm{mm} . \mathrm{Hg}$. This proceeding seemed justified since the voluntary effort of resisting the cuff was fatiguing and not usually sustained. Most subjects quickly adjusted themselves to the compression and relaxed.

Renal venous pressure partook in the generalized rise of intra-abdominal pressure. In 9 subjects (Table I) the control renal venous pressure of $5.8 \mathrm{~mm}$. $\mathrm{Hg}$ increased to $18.3 \mathrm{~mm}$. on the average. A similar increase of pressure in the upper portion of the inferior vena cava was observed twice (C. W. and O. C., Table I). It is probable that mean arterial pressure within the abdomen was not altered since extra-arterial pressures lower than diastolic pressure cannot affect intraarterial mean pressure (14). Hence, the head of pressure at the beginning of the renal circuit probably did not rise during compression while the venous pressure increased 3- to 4-fold. Such a change in the gradient of pressure along the renal vascular tree might be expected to result in a reduction of renal blood flow. This expectation was borne out by clearance studies.

\section{The effective renal blood flow}

Figure 1 illustrates the renal hemodynamic response to abdominal compression. In this subject (J. S.), the effective renal plasma flow (sodium p-aminohippurate clearance, $\mathrm{C}_{\mathbf{P A H}}$ ) remained relatively unchanged during the control periods, but fell strikingly from an average of 827 ml. per minute to $270 \mathrm{ml}$. per minute during pres-

TABLE II

Effect of increased intra-abdominal pressure on renal plasma flow and glomerular filtration rate All figures, with the exception of those marked with an asterisk, are averages of 2 or more periods.

\begin{tabular}{|c|c|c|c|c|c|c|c|c|c|c|c|}
\hline \multirow[b]{2}{*}{ Subject } & \multirow[b]{2}{*}{ Sex } & \multirow[b]{2}{*}{ Age } & \multicolumn{3}{|c|}{ Control } & \multicolumn{3}{|c|}{ During pressure } & \multicolumn{3}{|c|}{ Recovery } \\
\hline & & & $\begin{array}{c}\text { Glomer- } \\
\text { ular } \\
\text { filtration } \\
\text { rate }\end{array}$ & $\begin{array}{c}\text { Effective } \\
\text { renal } \\
\text { plasma } \\
\text { flow }\end{array}$ & $\begin{array}{l}\text { Filtration } \\
\text { fraction }\end{array}$ & $\begin{array}{c}\text { Glomer- } \\
\text { ular } \\
\text { filtration } \\
\text { rate }\end{array}$ & $\begin{array}{c}\text { Effective } \\
\text { renal } \\
\text { plasma } \\
\text { flow }\end{array}$ & $\begin{array}{l}\text { Filtration } \\
\text { fraction }\end{array}$ & $\begin{array}{l}\text { Glomer- } \\
\text { ular } \\
\text { filtration } \\
\text { rate }\end{array}$ & $\begin{array}{c}\text { Effective } \\
\text { renal } \\
\text { plasma } \\
\text { flow }\end{array}$ & $\begin{array}{l}\text { Filtration } \\
\text { fraction }\end{array}$ \\
\hline $\begin{array}{l}\text { H. B. } \\
\text { P. K. } \\
\text { A. N. } \\
\text { A. C. } \\
\text { N. P. } \\
\text { J.S. } \\
\text { M. E. } \\
\text { J. Q. }\end{array}$ & $\begin{array}{l}\text { Male } \\
\text { Male } \\
\text { Female } \\
\text { Female } \\
\text { Female } \\
\text { Female } \\
\text { Female } \\
\text { Male }\end{array}$ & $\begin{array}{l}21 \\
43 \\
45 \\
31 \\
27 \\
26 \\
43 \\
42\end{array}$ & $\begin{array}{c}\text { ml. per } \\
\text { min. } \\
102.0 \\
113.0 \\
128.0 \\
87.5 \\
94.8 \\
125.3 \\
122.7 \\
143.4\end{array}$ & $\begin{array}{c}\text { ml.per } \\
\text { min. } \\
827 \\
536 \\
655 \\
541 \\
625 \\
827 \\
540 \\
834\end{array}$ & $\begin{array}{c}\text { per cent } \\
12.3 \\
21.0 \\
19.5 \\
17.8 \\
15.1 \\
15.2 \\
22.7 \\
17.6\end{array}$ & $\begin{array}{c}\text { ml. per } \\
\text { min. } \\
* 67.6 \\
\text { *83.5 } \\
120.7 \\
81.8 \\
66.7 \\
43.8 \\
107.0 \\
143.7\end{array}$ & $\begin{array}{c}\text { ml. per } \\
\text { min. } \\
640 \\
432 \\
581 \\
437 \\
437 \\
269 \\
399 \\
884\end{array}$ & $\begin{array}{c}\text { per cent } \\
10.6 \\
19.3 \\
20.8 \\
18.7 \\
15.3 \\
16.2 \\
27.7 \\
16.3\end{array}$ & $\begin{array}{r}\text { ml.per } \\
\text { min. } \\
* 98.5 \\
* 139.7 \\
112.0 \\
83.0 \\
100.7 \\
117.5 \\
157.0 \\
153.1\end{array}$ & $\begin{array}{l}\text { ml. per } \\
\text { min. } \\
764 \\
686 \\
559 \\
388 \\
656 \\
697 \\
486 \\
966\end{array}$ & $\begin{array}{c}\text { per cent } \\
13.0 \\
20.4 \\
20.1 \\
22.1 \\
15.4 \\
16.8 \\
32.2 \\
15.9\end{array}$ \\
\hline
\end{tabular}




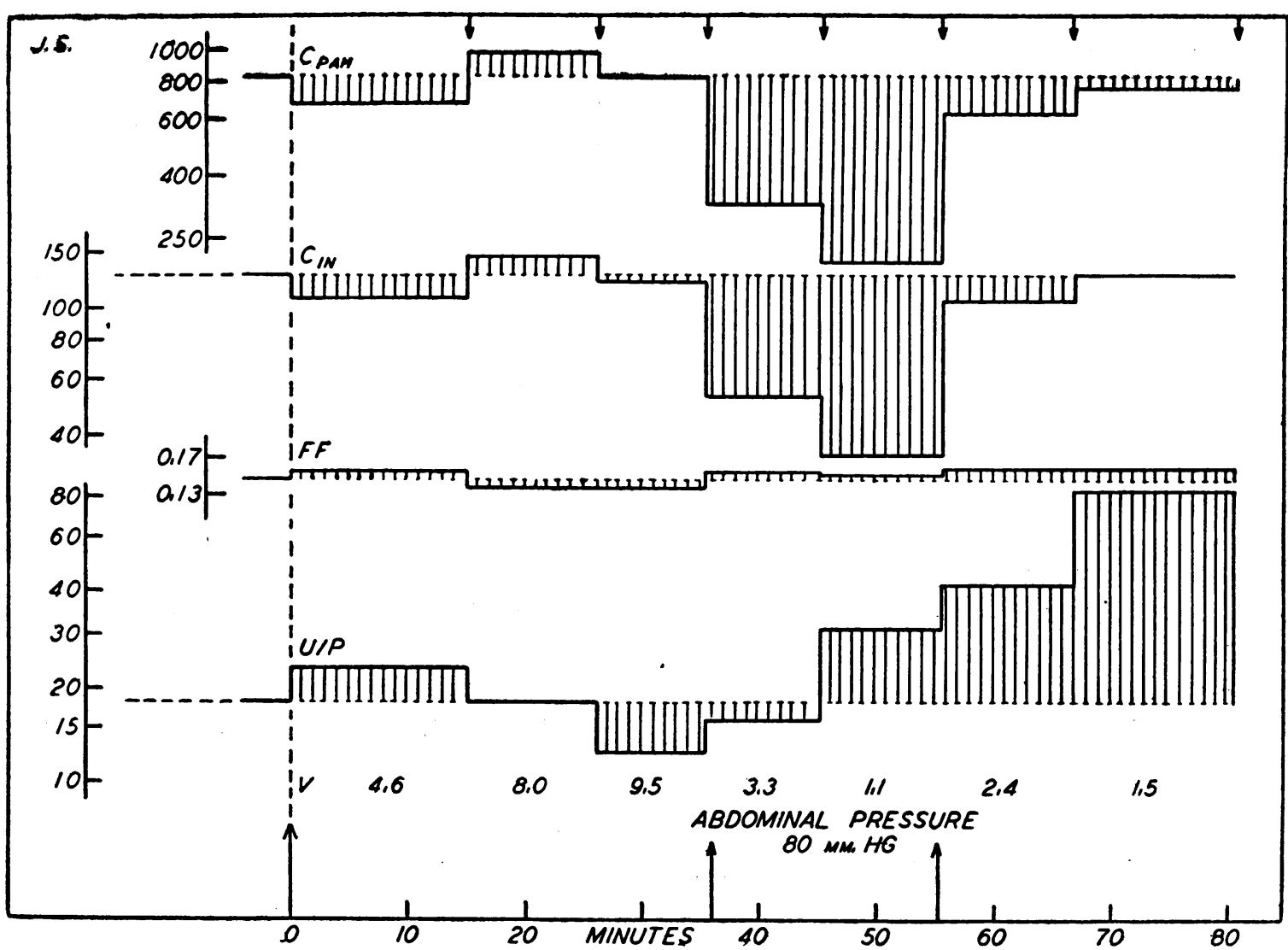

Fig. 1. Alterations in Effective Renal Plasma Flow and Glomerular Filtration Rate During Abdominal Compression in Subject J. S.

The effective renal plasma flow ( $\mathrm{ml}$. per min.) measured by the p-aminohippurate clearance $\left(\mathrm{C}_{\mathrm{P \Delta B}}\right)$ and the glomerular filtration rate $\left(\mathrm{ml}\right.$. per min.) measured by the inulin clearance $\left(\mathrm{C}_{\mathrm{IN}}\right)$ were determined during the application of $80 \mathrm{~mm}$. $\mathrm{Hg}$ pressure to the abdominal wall. The filtration fraction (FF), the percentage of plasma filtered $\left(\mathrm{C}_{\mathrm{IN}} / \mathrm{C}_{\mathrm{PAB}}\right)$, remained unchanged throughout. During compression the concentration ratio of inulin (U/P) increased and continued to rise after the pressure was released. Urine flow (V) (ml. per min.) fell markedly. Arrows at the top of the chart indicate the time of urine collection.

surization. There was a rapid return to the control level following the release of pressure.

Likewise, in 7 of the 8 subjects (Table II) in which it was determined, the effective renal plasma flow was reduced, although the average reduction was not so large in the other subjects as in J. S. In several individuals, during 1 or more periods immediately after the application of the abdominal cuff, the reduction in effective renal plasma flow was as large as that seen in J. S., but these changes are minimized in the calculation of the average figure by the inclusion of periods in which evidence of circulatory readjustment was observed. In these subjects, where the time of observation was sufficiently prolonged (more than 30 minutes of compression), the effective renal plasma flow and other renal functions ( 4 of 10 studies) showed a return toward the control values despite continued compression." Nevertheless, when all the figures were averaged disregarding this fact and including $\mathrm{J}$. Q., in whom abdominal compression produced no change (possibly because of abdominal muscular resistance), it was found that effective renal plasma flow was reduced from $673 \mathrm{ml}$. per minute to $509 \mathrm{ml}$. per minute, an average reduction of 24.4 per cent.

4 Figure 2 (J. W.) illustrates such an adjustment of the maximal tubular diodrast excretory rate $\left(T m_{D}\right)$ and the glomerular filtration rate $\left(\mathrm{C}_{\mathrm{IN}}\right)$. Effective renal plasma flow was not measured. 
It is noteworthy that renal hyperemia did not occur following the period of compressional ischemia. Occasionally very short urine periods collected immediately after release of pressure yielded high clearance values. These anomalous values may be attributed to a relatively larger contribution of dead-space urine to the total. Usually, however, high clearance values during recovery were absent. Indeed, the averaged figures of Table II reveal that effective renal plasma flow during recovery tended to be lower than during the control period. The absence of reactive hyperemia in the kidney observed during this study is in agreement with a large body of evidence obtained by others in the study of the renal circulation in man and other mammals $(15,16)$.

Proteinuria. It has been repeatedly demonstrated that a reduction of renal blood flow fol-. lowing obstruction to renal venous drainage is associated with the appearance of proteinuria (17). With abdominal pressure also, it was found that protein appeared in the urine in variable amounts. In 1 subject who had no history of previous renal disease and who was in good health, a $2+$ proteinuria developed during the application of the abdominal cuff. On most occasions, however, the proteinuria was not striking, although it occurred regularly.

$V$ alidity of the method of renal blood flow measurement. It is possible that these changes in clearance values were caused by errors inherent in the method of measurement.rather than by alterations of renal plasma flow. If pressure reduced the capacity of renal tubular cells to remove $\mathrm{PAH}$ from the blood, the clearance value would fall because of incomplete clearance of PAH. Or, if blood were shunted away from tubular tissue into the veins so that an opportunity for complete clearance were lacking, the clearance value might be decreased despite an absence of change (or even an increase) in blood flow.

The determination of renal $\mathrm{PAH}$ extraction, using the catheterization technique, provided the answer to this problem. The data summarized in Table III reveal that no change in $\mathrm{PAH}$ extraction occurred during compression. Hence, the clearance of PAH and, by analogy, of digdrast, provides an accurate measure of the behavior of renal plasma flow during increased abdominal pres-
TABLE III

Renal extraction of sodium p-aminohippurate before, during, and after abdominal compression

\begin{tabular}{c|c|c|c}
\hline \hline Subject & Control & $\begin{array}{c}\text { Abdominal } \\
\text { compression }\end{array}$ & Recovery \\
\hline & per cent & per cent & per cent \\
C. M. & 90.0 & 93.6 & 93.8 \\
D. C. & 91.0 & 93.2 & 91.9 \\
S. G. & 92.8 & 94.0 & 93.5 \\
O. C. & 94.2 & 90.7 & - \\
M. B. & 93.8 & 95.3 & 95.8 \\
F. H. & 90.5 & 91.5 & 92.5 \\
M. H. & 92.1 & 92.3 & - \\
L. J. & 94.5 & 93.2 & 91.6 \\
\hline
\end{tabular}

sure. In addition, the possibility that arteriovenous shunting occurs during increased pressure is excluded by this evidence.

Storage of $\mathrm{PAH}$ or diodrast during compression by nephrons that continue to be capable of excretory activity although unable to contribute to urine formation, might also introduce an error in the clearance determination that would elude detection in the measurement of the extraction ratio. However, this phenomenon would necessarily result in falsely high clearance values during recovery as a result of storage wash-out, and the relationship between calculated filtration rate and effective renal plasma flow would be thus altered artificially. This effect was never observed.

It appears that the clearance technique may be used with confidence under these conditions for the measurement of effective renal plasma flow, since extraction of $\mathrm{PAH}$ was not altered and storage probably did not occur.

\section{Glomerular filtration rate and filtration fraction}

The glomerular filtration rate was nearly always greatly reduced. Among the group collated in Table II, filtration fell to $88.4 \mathrm{ml}$. per minute (on the average) from the control level of $117.2 \mathrm{ml}$. per minute, a 27.5 per cent decrease. This observation was repeatedly confirmed in other studies in which renal plasma flow was not measured (see Table IV). Of particular significance is the fact that glomerular filtration was reduced to the same extent as the effective renal plasma flow. This equal percentile reduction was not a statistical accident but was observed whenever renal plasma flow decreased, as in Figure 1. Consequently, the ratio between filtration and plasma flow, the filtra- 
TABLE IV

Effect of increased intra-abdominal pressure on urine flow and urinary concentration

The urinary concentration is expressed as the concentration ratio of inulin or mannitol calculated by dividing the urinary concentration by the plasma concentration. All $U / P$ ratios are averages of 2 or more periods with the exception of those obtained during compression. These values are the maximal concentrations observed and they are presented with figures for filtration rate and urine flow determined simultaneously. All other values, except those marked with an asterisk, are averages of 2 or more periods.

\begin{tabular}{|c|c|c|c|c|c|c|c|c|c|}
\hline \multirow{2}{*}{ Subject } & \multicolumn{3}{|c|}{ Control } & \multicolumn{3}{|c|}{ Abdominal pressure } & \multicolumn{3}{|c|}{ Recovery } \\
\hline & $\begin{array}{l}\text { Glomerular } \\
\text { filtration } \\
\text { rate }\end{array}$ & $\begin{array}{l}\text { Urinary } \\
\text { concen- } \\
\text { tration }\end{array}$ & Urine flow & $\begin{array}{c}\text { Glomerular } \\
\text { filtration } \\
\text { rate }\end{array}$ & $\begin{array}{l}\text { Urinary } \\
\text { concen- } \\
\text { tration }\end{array}$ & Urine flow & $\begin{array}{l}\text { Glomerular } \\
\text { filtration } \\
\text { rate }\end{array}$ & $\begin{array}{l}\text { Urinary } \\
\text { concen- } \\
\text { tration }\end{array}$ & Urine flow \\
\hline $\begin{array}{l}\text { P. K. } \\
\text { A. N. } \\
\text { A. C. } \\
\text { N. P. } \\
\text { S. Q. } \\
\text { M.S. } \\
\text { J. Si. } \\
\text { L. R. } \\
\text { M. P. } \\
\text { L. R. } \\
\text { H. B. } \\
\text { J. S. } \\
\text { J. W. } \\
\text { M. E. } \\
\text { L. G. } \\
\text { H. B. } \\
\text { J. Q. }\end{array}$ & $\begin{array}{c}\text { ml. per min. } \\
127.5^{*} \\
128.0 \\
87.2 \\
94.8 \\
143.0 \\
97.5 \\
155.0 \\
126.8 \\
114.9 \\
98.8 \\
102.0 \\
125.3 \\
123.9 \\
122.7 \\
111.0 \\
98.0 \\
143.4\end{array}$ & $\begin{array}{r}40.0^{*} \\
29.0 \\
25.1 \\
27.5 \\
17.6 \\
27.4 \\
16.9 \\
11.9 \\
11.3 \\
8.4 \\
24.8 \\
18.2 \\
6.7 \\
8.5 \\
12.8 \\
28.1 \\
17.6\end{array}$ & $\begin{array}{c}\text { ml. per min. } \\
3.1^{*} \\
4.4 \\
3.5 \\
3.5 \\
8.2 \\
3.5 \\
9.2 \\
10.9 \\
10.0 \\
11.8 \\
4.1 \\
7.4 \\
18.4 \\
12.1 \\
9.3 \\
3.5 \\
8.2\end{array}$ & $\begin{array}{c}\text { ml. per min. } \\
83.5 \\
116.3 \\
80.0 \\
43.7 \\
144.0 \\
79.0 \\
110.0 \\
112.7 \\
67.4 \\
57.7 \\
67.6 \\
34.3 \\
80.9 \\
108.8 \\
79.6 \\
72.0 \\
144.0\end{array}$ & $\begin{array}{l}39.0 \\
38.1 \\
28.2 \\
27.1 \\
24.9 \\
36.6 \\
26.5 \\
34.7 \\
20.0 \\
24.5 \\
33.2 \\
23.5 \\
40.5 \\
34.4 \\
15.9 \\
31.3 \\
25.0\end{array}$ & $\begin{array}{c}\text { ml. per min. } \\
2.4 \\
3.1 \\
2.8 \\
1.6 \\
5.7 \\
2.2 \\
4.2 \\
3.2 \\
3.4 \\
2.4 \\
2.0 \\
1.1 \\
2.0 \\
3.3 \\
5.0 \\
2.3 \\
5.8\end{array}$ & $\begin{array}{c}\text { ml. per min. } \\
139.7^{*} \\
113.0 \\
86.0 \\
100.0 \\
153.1 \\
115.3 \\
193.9 \\
126.8 \\
105.4 \\
112.5^{*} \\
98.5^{*} \\
117.5 \\
144.7 \\
157.0 \\
120.2^{*} \\
78.5 \\
153.1\end{array}$ & $\begin{array}{l}38.3^{*} \\
37.0 \\
28.0 \\
32.1 \\
22.9 \\
28.8 \\
21.9 \\
29.3 \\
16.1 \\
21.2^{*} \\
32.8^{*} \\
64.7 \\
58.6 \\
31.1 \\
15.8^{*} \\
32.0 \\
22.9\end{array}$ & $\begin{array}{l}\text { ml. per mix. } \\
3.6^{*} \\
3.0^{*} \\
3.0 \\
3.1 \\
6.7 \\
3.9 \\
8.8 \\
4.3 \\
6.7 \\
5.3^{*} \\
3.0^{*} \\
1.9 \\
2.4 \\
5.0 \\
7.6^{*} \\
2.5 \\
6.7\end{array}$ \\
\hline
\end{tabular}

tion fraction, or the percentage of plasma filtered at the glomerulus, remained constant. This fact is clearly shown in Figure 1 and Table II. Moreover, in most instances, the filtration fraction remained constant during adjustment to compression or during recovery.

\section{B. Tubular function during abdominal compression}

\section{Tubular reabsorption of water}

Urine flow decreased strikingly immediately after the application of abdominal compression in every subject (Table IV) even in the presence of diuresis during the control period. The reduction in filtration rate had little influence in producing this effect per se, since the urinary concentration usually increased markedly, indicating the operation of increased tubular water reabsorption as the cause of the oliguria.

In Table IV, the maximal concentration change is presented in terms of mannitol or inulin urine: plasma concentration ratios denoting the extent to which these substances are concentrated in the tubular urine by the active reabsorption of water.

TABLE V

Effect of increased intra-abdominal pressure upon maximal glucose reabsorptive capacity (TmG) in normal subjects All values except those marked with an asterisk are averages of 2 or more periods.

\begin{tabular}{|c|c|c|c|c|c|c|c|c|c|c|c|c|c|c|}
\hline \multirow[b]{2}{*}{$\begin{array}{l}\text { Sub- } \\
\text { ject }\end{array}$} & \multirow[b]{2}{*}{ Sex } & \multirow[b]{2}{*}{ Age } & \multicolumn{4}{|c|}{ Control } & \multicolumn{4}{|c|}{ Pressure } & \multicolumn{4}{|c|}{ Recovery } \\
\hline & & & $\begin{array}{l}\text { Plasma } \\
\text { concen- } \\
\text { tration } \\
\text { glucose }\end{array}$ & $\begin{array}{c}\text { Load } \\
\text { glucose } \\
\underset{T \mathbf{T}}{\text { Glucose }}\end{array}$ & $\begin{array}{l}\text { Glucose } \\
\text { Tm }\end{array}$ & $\begin{array}{c}\text { Glomer- } \\
\text { ular } \\
\text { filtra- } \\
\text { tion } \\
\text { rate } \\
\begin{array}{c}\text { Glucose } \\
\text { Tm }\end{array}\end{array}$ & $\begin{array}{l}\text { Plasma } \\
\text { concen- } \\
\text { tration } \\
\text { glucose }\end{array}$ & 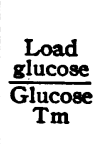 & $\underset{\text { Tm }}{\text { Glucose }}$ & $\begin{array}{c}\begin{array}{c}\text { Glomer- } \\
\text { ular } \\
\text { fltra- } \\
\text { tion } \\
\text { rate }\end{array} \\
\begin{array}{c}\text { Glucose } \\
\text { Tm }\end{array}\end{array}$ & $\begin{array}{l}\text { Plasma } \\
\text { concen- } \\
\text { tration } \\
\text { glucose }\end{array}$ & $\frac{\text { Load }}{\text { glucose }}$ & $\underset{\text { Tm }}{\text { Glucose }}$ & $\begin{array}{c}\text { Glomer- } \\
\text { ular } \\
\text { fltra- } \\
\text { tion } \\
\text { rate } \\
\begin{array}{c}\text { Glucose } \\
\text { Tm }\end{array}\end{array}$ \\
\hline $\begin{array}{l}\text { L. R. } \\
\text { L. G. } \\
\text { J. Si. } \\
\text { J. Q. } \\
\text { M. E. }\end{array}$ & $\begin{array}{l}\text { Male } \\
\text { Female } \\
\text { Male } \\
\text { Male } \\
\text { Female }\end{array}$ & $\begin{array}{l}30 \\
28 \\
17 \\
43 \\
43\end{array}$ & $\begin{array}{c}\text { mgm. } \\
\text { per cent } \\
302 \\
535 \\
522 \\
497 \\
549\end{array}$ & $\begin{array}{l}1.55 \\
1.69 \\
2.51 \\
1.60 \\
1.81\end{array}$ & $\begin{array}{c}\text { mgm. } \\
\text { per mix. } \\
245.6 \\
353.0 \\
327.8 \\
459.3 \\
373.0\end{array}$ & $\begin{array}{l}0.514 \\
0.348 \\
0.483 \\
0.315 \\
0.329\end{array}$ & $\begin{array}{c}\text { mgm. } \\
\text { per cent } \\
259 \\
512 \\
516 \\
459 \\
497\end{array}$ & $\begin{array}{l}1.46 \\
1.71 \\
2.42 \\
1.52 \\
1.55\end{array}$ & $\begin{array}{c}\text { mgm. } \\
\text { per min. } \\
185.4 \\
252.1 \\
238.0 \\
435.7 \\
344.0\end{array}$ & $\begin{array}{l}0.560 \\
0.330 \\
0.469 \\
0.330 \\
0.327\end{array}$ & $\begin{array}{c}\text { mgm. } \\
\text { per cent } \\
231 \\
482^{*} \\
495^{*} \\
443 \\
490^{*}\end{array}$ & $\begin{array}{l}1.20 \\
1.64^{*} \\
2.78^{*} \\
1.47^{*} \\
1.83^{*}\end{array}$ & $\begin{array}{c}\underset{\text { mgm. }}{\text { per min. }} \\
229.4 \\
351.0^{*} \\
356.0^{*} \\
427.8 \\
421.0^{*}\end{array}$ & $\begin{array}{l}0.554 \\
0.342 * \\
0.520^{*} \\
0.359 \\
0.330^{*}\end{array}$ \\
\hline
\end{tabular}


All other substances examined likewise showed an increase in concentration.

There was no evidence favoring the possibility that ureteral obstruction by the compressing abdominal cuff might account for the oliguria. Following release of the cuff, the urine flow continued to be depressed in most instances. A sudden increase of urine flow following pressure release, due to the outflow of impounded urine, was never observed. Moreover, the change in clearance values and urine flow was observed on 2 occasions when the ureters were catheterized and pressure applied to the abdominal wall.

\section{Tubular transfer maxima ( $T m$ )}

The maximal tubular reabsorption of glucose and the maximal tubular excretion of diodrast were reduced by abdominal compression (Tables $\mathrm{V}$ and VI). Glucose Tm was measured in $5 \mathrm{sub}-$ jects. In 2 (J. Q. and M. E.), the Tm value was not significantly reduced, possibly because of reduced pressure transmission. In the remaining subjects, glucose $\mathrm{Tm}$ fell strikingly from 35 to 24.5 per cent on the average. Greater falls during individual periods are masked by the inclusion in the average value of periods in which readjustment had taken place. Among the subjects in whom diodrast $\mathrm{Tm}$ was determined, significant average reductions were noted on every occasion during compression. During the recovery phase, the $\mathrm{Tm}$ values returned to the control level and, on several occasions, somewhat above it, possibly as a result of dead-space error. It will be noted that the reduction ranged between 39 and 23.4 per cent. In all subjects, exclusive of those in whom no significant change was observed, the average reduction of glucose and diodrast $\mathrm{Tm}$ was of the same order of magnitude as the average reduction of effective renal plasma flow and glomerular filtration.

When the relation between filtration rate and the simultaneously determined $\mathrm{Tm}$ value was examined, it was found that the maximal tubular transfer of either glucose or diodrast varied more or less directly with the filtration. Figures 2 and 3 illustrate this relationship. It can be seen that the ratio between $\mathrm{Tm}$ and filtration rate remained relatively constant throughout. Table $\mathrm{V}$ reveals that this ratio did not change significantly on the average in the case of maximal tubular glucose reabsorption. In 2 of the 5 subjects in whom diodrast Tm was measured, however (Table VI), there was a significant depression of the ratio (L. R. and M. P.). In these instances the inclusion of high values observed in the control period and the possible operation of intra-renal vasoconstriction may have been responsible for the alteration. On the whole, it appeared that the maximal rate of tubular transfer of glucose and diodrast was reduced by abdominal compression to about the same extent as the glomerular filtration rate and effective renal plasma flow.

Validity of the methods of the measurement. The observed reduction in maximal tubular transfer capacity could be ascribed to inadequate loading of the intracellular mechanisms by glucose or

TABLE VI

Effect of increased intra-abdominal pressure upon maximal diodrast excretory capacity (TmD)

All values, except those marked with an asterisk, are averages of 2 or more periods.

\begin{tabular}{|c|c|c|c|c|c|c|c|c|c|c|c|c|c|c|}
\hline \multirow[b]{2}{*}{ Sub- } & \multirow[b]{2}{*}{ Sex } & \multirow[b]{2}{*}{ Age } & \multicolumn{4}{|c|}{ Control } & \multicolumn{4}{|c|}{ Pressure } & \multicolumn{4}{|c|}{ Recovery } \\
\hline & & & $\begin{array}{l}\text { Plasma } \\
\text { concen- } \\
\text { tration } \\
\text { diodrast }\end{array}$ & 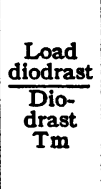 & $\underset{\mathrm{Tm}}{\text { Diodrast }}$ & $\begin{array}{c}\text { Glomer- } \\
\text { ular } \\
\text { filtra- } \\
\text { tion } \\
\text { rate } \\
\begin{array}{c}\text { Dio- } \\
\text { drast } \\
\text { Tm }\end{array}\end{array}$ & $\begin{array}{l}\text { Plasma } \\
\text { concen- } \\
\text { tration } \\
\text { diodrast }\end{array}$ & $\frac{\begin{array}{c}\text { Load } \\
\text { diodrast }\end{array}}{\begin{array}{c}\text { Dlo- } \\
\text { drast } \\
\text { Im }\end{array}}$ & $\underset{\text { Tm }}{\text { Diodrast }}$ & $\begin{array}{c}\begin{array}{c}\text { Glomer- } \\
\text { ular } \\
\text { filtra- } \\
\text { tion } \\
\text { rate }\end{array} \\
\begin{array}{c}\text { Dio- } \\
\text { drast } \\
\text { Tm }\end{array}\end{array}$ & $\begin{array}{l}\text { Plasma } \\
\text { concen- } \\
\text { tration } \\
\text { diodrast }\end{array}$ & $\frac{\begin{array}{c}\text { Load } \\
\text { diodrast }\end{array}}{\begin{array}{c}\text { Dio- } \\
\text { drast } \\
\text { Tm }\end{array}}$ & $\underset{\text { Tm }}{\text { Diodrast }}$ & $\begin{array}{c}\text { Glomer- } \\
\text { ular } \\
\text { filtra- } \\
\text { tion } \\
\text { rate } \\
\text { Dio- } \\
\begin{array}{c}\text { drast } \\
\text { Tm }\end{array}\end{array}$ \\
\hline $\begin{array}{l}\text { M. S. } \\
\text { L. R. } \\
\text { M. P. } \\
\text { L. G. } \\
\text { J. W. }\end{array}$ & $\begin{array}{l}\text { Female } \\
\text { Male } \\
\text { Male } \\
\text { Female } \\
\text { Female }\end{array}$ & $\begin{array}{l}50 \\
30 \\
16 \\
28 \\
29\end{array}$ & $\begin{array}{c}\text { mgm. } \\
\text { per cent } \\
12.8 \\
14.5 \\
16.0 \\
19.0 \\
23.0\end{array}$ & $\begin{array}{l}1.07 \\
1.37 \\
1.92 \\
2.60 \\
2.96\end{array}$ & $\begin{array}{c}\text { mgm. } \\
\text { per min. } \\
50.1 \\
44.5 \\
40.5 \\
41.5 \\
57.2\end{array}$ & $\begin{array}{l}1.94 \\
2.23 \\
2.84 \\
2.67 \\
2.17\end{array}$ & $\begin{array}{c}\text { mgm. } \\
\text { per cent } \\
11.6 \\
13.1 \\
17.7 \\
17.8 \\
17.9\end{array}$ & $\begin{array}{l}1.05 \\
0.95 \\
2.11 \\
2.37 \\
2.24\end{array}$ & $\begin{array}{c}\text { mgm. } \\
\text { per min. } \\
36.9 \\
36.4 \\
26.6 \\
31.8 \\
34.8\end{array}$ & $\begin{array}{l}2.09 \\
1.75 \\
2.12 \\
2.59 \\
2.33\end{array}$ & 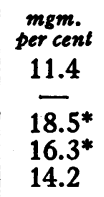 & $\begin{array}{l}1.13 \\
2.06^{*} \\
2.45^{*} \\
2.14\end{array}$ & $\begin{array}{c}\text { mgm. } \\
\text { per min. } \\
47.3 \\
\overline{48.6^{*}} \\
47.6^{*} \\
55.4\end{array}$ & $\begin{array}{l}2.08 \\
2.03^{*} \\
2.53^{*} \\
2.61\end{array}$ \\
\hline
\end{tabular}




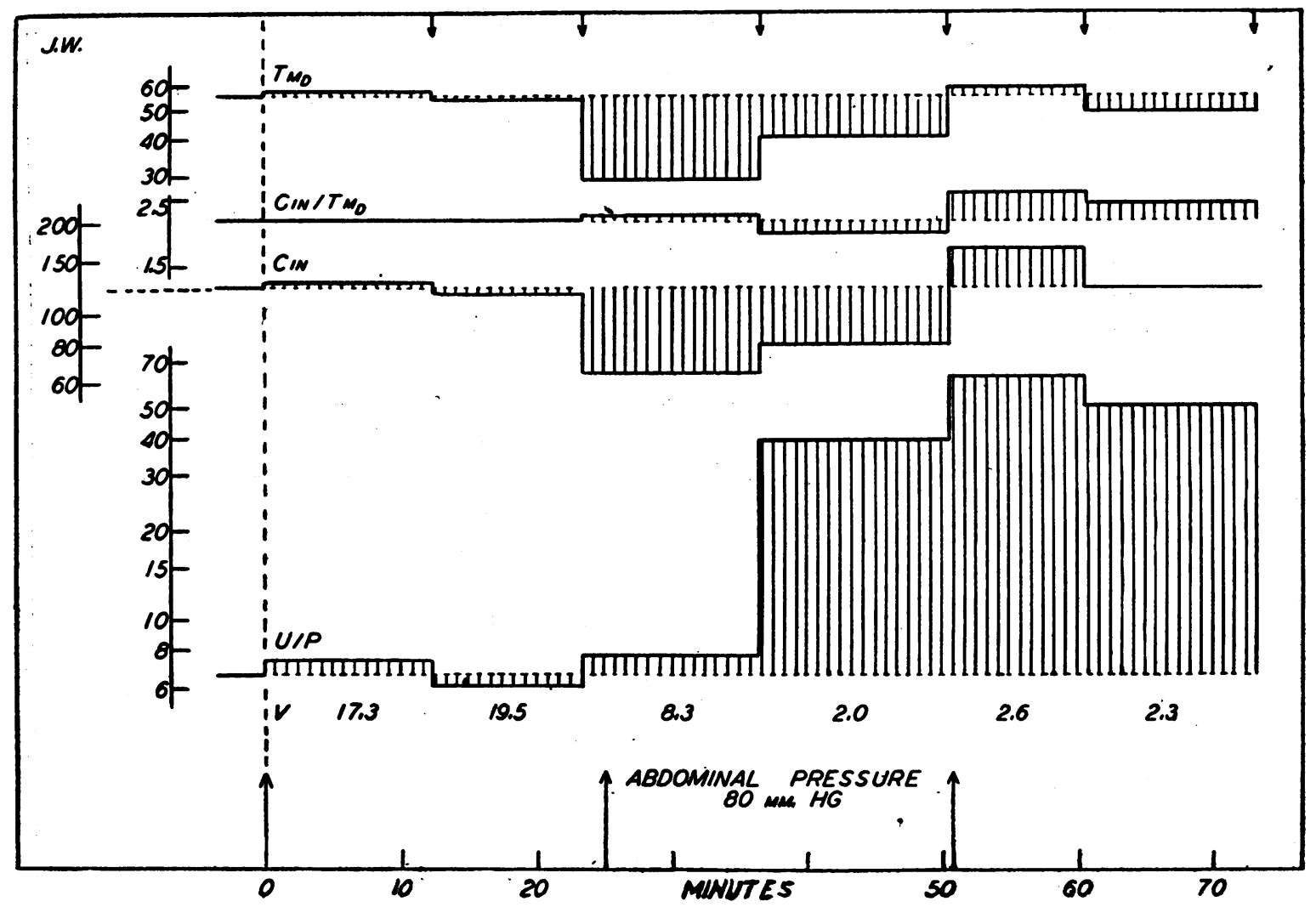

Fig. 2. Alteration in Maximal Tubular Diodrast Excretory Rate (Diodrast Tm) and Glomerular Filtration Rate during Abdominal Compression in Subject J. W.

Diodrast $T m$ ( $\left.T m_{D}\right)$ (mgm. per min.) and glomerular filtration rate $\left(\mathrm{C}_{\mathrm{IN}}\right)$ ( $\mathrm{ml}$. per min.) fell during increased intra-abdominal pressure while the inulin $U / P$ ratio rose. The relation between glomerular filtration rate and diodrast $\mathrm{Tm}\left(\mathrm{C}_{\mathrm{IN}} / \mathrm{T}_{\mathrm{m}}\right)$, remained unchanged throughout. It can be seen that both diodrast $\mathrm{Tm}$ and the filtration rate increased late in the period of pressure application. Urine flow (V) (ml. per min.) was markedly depressed.

diodrast, either as a result of over-all renal ischemia and lowered filtration rate or focal ischemia and localized slowing of filtration. In the first instance, the smaller carriage of diodirast or glucose would result in a failure to supply sufficient material for saturation of the whole kidney and, in the second, adequate over-all loading would mask focal ischemia and failure to saturate tubular transfer mechanisms in discrete localized regions.

a. over-all loading. The calculated load of glucose presented to the tubules for reabsorption should exceed the tubular capacity by 20 per cent and the quantity of diodrast carried in the plasma to the tubules ${ }^{5}$ should exceed the excretory capac-

\footnotetext{
${ }^{5}$ The load of glucose brought in the glomerular filtrate to the tubule cells for reabsorption was calculated as the arterial plasma concentration of glucose (mgm.
}

ity by 100 per cent (8) to assure adequate saturation. In every instance the load to $\mathrm{Tm}$ ratio for glucose was greater than 1.2 (Table V). On 2 occasions (M. S. and L.R.), the diodrast load fell below the prescribed limit (Table VI). Considering the fact that the decrements in diodrast $\mathrm{Tm}$ in

per $\mathrm{ml}$. ) times the filtration rate ( $\mathrm{ml}$. per min.). The diodrast load is the amount of diodrast carried in the plasma to the tubules less that removed by filtration. It was calculated as the plasma concentration of diodrast (mgm. per $\mathrm{ml}$.) times the estimated effective renal plasma flow, less the plasma concentration of diodrast (mgm. per ml.) multiplied by the filtration rate ( $\mathrm{ml}$. per min.) and a factor $(0.72)$ to correct for protein binding. Since effective renal plasma flow cannot be determined at high plasma levels of diodrast, it was estimated on the basis of the observed filtration rate, assuming a normal value of 20 per cent for the filtration fraction. 


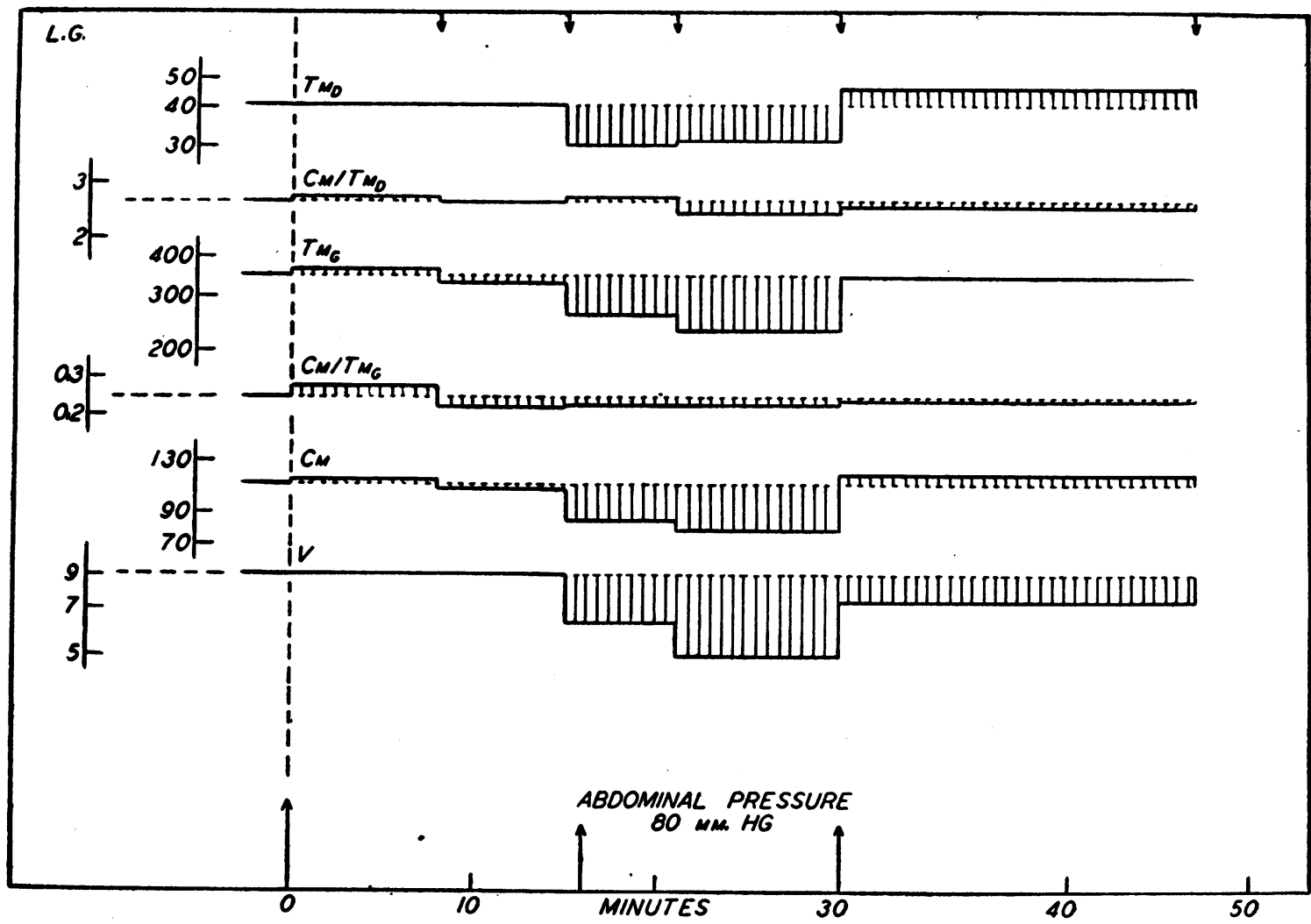

Fig. 3. Alterations of Maximal Tubular Diodrast Excretory Rate (Diodrast Tm) and Maximal Tubular Glucose Reabsorption Rate (Glucose Ty) during Abdominal Compression in Subject L. G.

Diodrast $\mathrm{Tm}\left(\mathrm{Tm}_{\mathrm{D}}\right)$ ( $\mathrm{mgm}$. per min.) and glucose $\mathrm{Tm}\left(\mathrm{T} \mathrm{m}_{\mathfrak{G}}\right)$ (mgm. per min.) fell equally during compression. The relationships between the $\mathrm{Tm}$ values and the glomerular filtration rate measured by the mannitol clearance (Cus) remained constant. Urine flow (V) decreased, but returned toward the control level following the termination of the period of pressure.

these cases during pressure were of the same magnitude as those where the calculated loads were sufficiently high, it is possible that the calculated loads were erroneous. The calculation of diodrast load requires an estimation of the renal plasma flow on the basis of the filtration rate, assuming a normal filtration fraction of 20 per cent. It is not unlikely that this assumption was in error in these instances and that the actual plasma flow was much greater. In any case, it is evident that inadequate loading cannot be the cause of the reduction in tubular activity during increased intra-abdominal pressure in most of these studies.

b. focal loading. Despite the demonstration that adequate loading did not prevent the fall in Tm observed during pressure, it might be argued that these figures, referable to the kidney as a whole, may fail to reveal focal inadequacies. This argument may be visualized and examined as follows.

For the purposes of discussion, the kidney may be divided into 4 concentric zones (Table VII)

TABLE VII

\begin{tabular}{|c|c|c|c|c|c|c|c|}
\hline Zone & $\begin{array}{c}\text { Reduc- } \\
\text { tion }\end{array}$ & $\begin{array}{l}\text { Filtra- } \\
\text { tion } \\
\text { rate }\end{array}$ & $\begin{array}{l}\text { Plasma } \\
\text { flow }\end{array}$ & $\begin{array}{l}\text { Load } \\
\text { glu- } \\
\text { cose }\end{array}$ & $\begin{array}{l}\text { Reab- } \\
\text { sorbed } \\
\text { glucose }\end{array}$ & $\begin{array}{l}\text { Load } \\
\text { dio- } \\
\text { drast }\end{array}$ & $\begin{array}{c}\text { Ex- } \\
\text { creted } \\
\text { diodrast }\end{array}$ \\
\hline$\underset{\text { III }}{\text { II }}$ & $\begin{array}{r}80 \% \\
50 \% \\
10 \% \\
0 \%\end{array}$ & $\begin{array}{c}\text { ml. } \\
\text { per } \\
\text { min. } \\
6 \\
15 \\
27 \\
30\end{array}$ & $\begin{array}{r}\text { ml. } \\
\text { per } \\
\text { min. } \\
25.0 \\
62.5 \\
112.5 \\
125.0\end{array}$ & $\begin{array}{r}\text { mgm. } \\
\text { per } \\
\text { min. } \\
36 \\
90 \\
162 \\
180\end{array}$ & $\begin{array}{r}\text { mgm. } \\
\text { per } \\
\text { min. } \\
36 \\
90 \\
100 \\
100\end{array}$ & $\begin{array}{c}\text { mgm. } \\
\text { per } \\
\text { min. } \\
6.3 \\
15.5 \\
27.8 \\
31.0\end{array}$ & $\begin{array}{c}\text { mgm. } \\
\text { per } \\
\text { min. } \\
6.3 \\
13.0 \\
13.0 \\
13.0\end{array}$ \\
\hline $\begin{array}{l}\text { Over-all } \\
\text { effect }\end{array}$ & $35 \%$ & 78 & 325.0 & 468 & 326 & 80.6 & 45.3 \\
\hline $\begin{array}{l}\text { Total } \\
\text { reduction }\end{array}$ & $35 \%$ & $35 \%$ & $35 \%$ & & $18.4 \%$ & & $12.9 \%$ \\
\hline
\end{tabular}


throughout each of which blood flow and filtration are regularly distributed, although great differences may exist between zones. ${ }^{\circ}$ It may be further assumed that the effect of compression is different in each zone (as the result of a gradient of pressure, for example, so that the compressional force is greater at the periphery than at the center), but that the effect in each zone is constant and regular throughout the entire region. During the control period, prior to compression, the over-all glomerular filtration rate, blood flow and transfer maxima of glucose and diodrast are equally divided among all the zones. The over-all glomerular filtration rate may be taken às $120 \mathrm{ml}$. per minute, the renal plasma flow as $500 \mathrm{ml}$. per minute, glucose $\mathrm{Tm}, 400 \mathrm{mgm}$. per minute, and diodrast $\mathrm{Tm}$, $52 \mathrm{mgm}$. per minute, while the glucose and diodrast plasma levels are maintained at $600 \mathrm{mgm}$. per cent and $30 \mathrm{mgm}$. per cent, respectively. With the application of a compressional force, the plasma flow and filtration rate may be assumed to undergo reductions of $80,50,10$, and 0 per cent in zones I to IV, respectively. The data tabulated in Table VII reveal that the percentile reductions in overall $\mathrm{Tm}$ thus produced do not equal the percentile reductions in plasma flow and filtration rate, and the reductions in diodrast and glucose $\mathrm{Tm}$ are not equivalent. The discrepancy in $\mathrm{Tm}$ values could be expected to vary greatly, depending upon the relative loading of the 2 tubular mechanisms. Therefore, it appears that the changes in tubular function observed during abdominal compression cannot be ascribed to focal ischemia due either to focal vasoconstrictive activity or to the operation of a gradient of pressure across the kidney.

\section{DISCUSSION}

It has been found that abdominal compression increases the pressure equally throughout the abdominal cavity and in doing so produces striking renal functional changes. Renal plasma flow and glomerular filtration are almost always reduced, together with the tubular activities of maximal glucose reabsorption and maximal diodrast excretion.

- It is obvious that the kidney may be further subdivided until each zone refers to a single nephron. Hence, what is said here with reference to 4 arbitrary and regularly placed renal zones would apply with equal force to discrete units distributed irregularly through the kidney.
All these functions are reduced to the same degree. Water reabsorption, on the other hand, is always enhanced, the urine flow decreases, and the urine becomes more concentrated.

Every effort was made to eliminate experimental error. Determinations of the renal extraction of sodium $\mathrm{p}$-aminohippurate have validated the use of the clearance technique in measuring the changes of renal blood flow. Arteriovenous shunting has been definitely ruled out by this method. Likewise, the alterations in glucose and diodrast $\mathrm{Tm}$ may be accepted as indicative of changes in tubular function, since it appears that inadequate loading or focal ischemia may be excluded as possible misleading factors.

On the basis of the averaged data, it seems likely that the increase of venous pressure during $a b$ dominal compression is usually sufficient to account for the reduction of renal plasma flow. Excluding J. S. and J. Q. (Table II) from consideration, the averaged figures may be used in calculating the reduction to be expected on the basis of an increment of venous pressure alone. ${ }^{7}$ If the pressure gradient across the renal circuit is assumed to change from $85 \mathrm{~mm}$. $\mathrm{Hg}$ to $70 \mathrm{~mm}$. $\mathrm{Hg}$ during compression as a result of an increase of renal venous pressure from $5 \mathrm{~mm}$. $\mathrm{Hg}$ to $20 \mathrm{~mm}$. $\mathrm{Hg}$ (the mean renal arterial pressure remaining constant at $90 \mathrm{~mm}$. $\mathrm{Hg}$ ), and, if the renal resistance does not change, the average renal plasma flow of 621 ml. per minute would fall to $512 \mathrm{ml}$. per minute. Actually, it was observed to fall to $488 \mathrm{ml}$. per minute, a somewhat greater decrease, which would require a venous pressure increment of $18 \mathrm{~mm}$. $\mathrm{Hg}$. It can be seen that the elevation of venous pressure alone is approximately sufficient to account for the observed change.

The reduction of renal plasma flow was much greater than average immediately following the application of pressure in many subjects and

I In any vascular bed of constant resistance, the relation of blood or plasma flow to the loss of pressure from the beginning to the end of the circuit remains constant. This relationship may be expressed as follows, where $F$ is the initial renal plasma flow; $P$, the initial difference in renal arterial and renal venous pressures; $F^{\prime}$ and $P^{\prime}$, these values when the pressure difference has been altered as with an increment of venous pressure:

$$
\begin{aligned}
F^{\prime} / P^{\prime} & =F / P \text { and } \\
F^{\prime} & =P^{\prime} F / P
\end{aligned}
$$


throughout the entire study in J. S. Although these facts may indicate the operation of vasoconstriction, it is not at all unlikely that venous pressure, in these instances, was higher than average as a result of compressional contraction of the abdominal musculature. The intra-abdominal pressure may be raised as high as the arterial pressure by this maneuver. On the other hand, muscular contraction may lower intra-abdominal pressure by thrusting away the pressure girdle, and it is possible that the adjustment to compression noted in some instances, where renal function gradually improved, may have arisen from this factor rather than from the release of vasoconstriction.

Although the increase in renal venous pressure seems to provide an adequate cause for the reduction in renal blood flow, it is at first difficult to account for the other changes in renal function on this basis. Certainly one might expect a change in filtration fraction similar to that attributed to efferent arteriolar vasoconstriction (18), since the elevation of the pressure gradient in the renal vascular bed should increase effective filtration pressure and the filtration rate should remain relatively constant despite the reduction in blood flow. Since an increment of venous pressure is equally effective in all parts of the renal vascular bed, there is no reason to expect a fall in diodrast and glucose $\mathrm{Tm}$. The fall in these values indicates the cessation of function in a number of nephrons and glomeruli proportional to the decrement in Tm (19).

The closure of afferent arterioles would produce changes in renal function similar to those observed. In obstructing blood flow, arteriolar closure would halt filtration in the glomerulus and, in consequence, abolish glucose reabsorption and diodrast excretion in the nephron dependent upon it. Although the tubule might remain in a normal state, it is obvious that glucose would no longer be brought to it for removal and that excreted diodrast would not be washed into the renal pelvis. Hence, the nephron would cease to contribute to $\mathrm{Tm}$ and the values for it would be reduced. In the remainder of the kidney, renal blood flow and glomerular filtration rate must continue undisturbed, since the filtration fraction and the relation between the clearance values and $\mathrm{Tm}$ are not altered by compression. Thus, afferent arterioles would be required to close completely or remain unconstricted. While this hypothesis satisfactorily accounts for many of the changes in renal function, it fails to consider the implications of the elevation of venous pressure.

It has been pointed out above that the increase in venous pressure is probably sufficient to account for the observed reduction in renal blood flow, but, under the conditions of afferent arteriolar constriction, it would be necessary to assume that increased resistance to flow is entirely responsible and that the venous pressure increment is without effect. It must be admitted, however, that diminished resistance in the remainder of the renal vascular bed is necessary to offset the rise in venous pressure. If such a vasodilation occurred in the efferent arterioles it is possible that blood flow and filtration rate might maintain a constant relationship to one another and to the $T m$ values as observed. However, it seems extremely unlikely that both vasoconstriction and vasodilation occur simultaneously in the kidney. An adjustment of efferent arteriolar tone in response to renal venous pressure has not been observed in other conditions, and it seems highly improbable that it occurs during abdominal compression. For these reasons the hypothesis that afferent arteriolar vasoconstriction results in functional amputation of a portion of the renal parenchyma may be dismissed as unacceptable.

In the discussion thus far, the fact that the pressure rises in the renal pelvis, opposing the outflow of urine, has not been considered. If the resistance to the flow of urine differs in different nephrons (as it may, since the tubules vary considerably in length), there may be a wide range of pressures at the terminal ends of the tubules. Elevation of pelvic pressure would then block urine outflow from those tubules in which the terminal pressures are lower than pelvic pressure. As a result, Tm values and the glomerular filtration rate would fall. In this situation the blood perfusing inactive glomeruli would continue to be cleared of diodrast or $\mathrm{p}$-aminohippurate by neighboring operative tubules and the filtration fraction would fall as a result of the reduction of filtration rate independently of blood flow. Since the renal venous pressure rises during abdominal compression, however, the filtration fraction in the active glomeruli would be increased and might be expected to mask the 
effect of the clearance of diodrast or p-aminohippurate from blood perfusing inactive glomeruli.

This hypothesis has the advantage of providing a simple explanation for all the changes observed in this study. Vasoconstriction would be unnecessary, the fall in blood flow being entirely accounted for by the increment in renal venous pressure. The demonstration by others (18) that the filtration rate in man tends to remain unchanged is supported by the finding that it does not change in the residual active glomeruli. Such reduction of filtration rate and Tm values as occurs is entirely attributable to the blockage of flow from "low-pressure" nephrons by the elevated pelvic pressure. It should be noted that equal elevations in renal venous pressure and pelvic pressure produce equal percentile changes in renal blood flow and in the mass of functioning tubular tissue, respectively, according to this hypothesis. The implications of such a relationship are not clear and are under further investigation.

Increased intrapelvic and intratubular pressure may be instrumental in raising the urinary concentration by stimulating the mechanisms of water transfer to greater activity. However, the psychic and physical stimulus of compression should provoke the release of antidiuretic hormone by the pituitary, since less severe stimuli have been found to have this action (20). In 1 subject with documented diabetes insipidus presenting marked diuresis as a result of withdrawal of pitressin, abdominal compression caused oliguria.

The pathological renal physiology of increased intra-abdominal pressure has been clarified by this study. Under the conditions imposed, retention of water and probably of salt occurs in spite of the presence of factors conducive to diuresis. The reduction of glomerular filtration rate and oliguria, if maintained for any length of time, would certainly prevent the normal excretion of urea, and azotemia would develop.

For the short period of time during which positive $G$ is experienced by airmen, abdominal compression sustains the cardiac output by the expression of blood into the thorax from the abdomen and by minimizing the gravitational effects upon the flow of blood from the inferior venous chamber into the superior chamber. The simultaneous reduction of arterial blood flow into the splanchnic bed also results in the diversion of a greater proportion of the cardiac output to the brain. It is likely that prolonged application of increased intra-abdominal pressure may be detrimental because the cardiac output is ultimately reduced by about the same extent as the blood flow through the kidneys and liver $(21,22)$. Hypotension and faintness were observed on several occasions during the course of this study in subjects not reported herein.

\section{SUMMARY}

The effective renal plasma flow, glomerular filtration rate, and tubular function have been measured in 17 normal human subjects by the clearance and saturation techniques during the application of a pneumatic abdominal girdle under pressure. Measurement of the venous pressure in the inferior vena cava and renal vein following venous catheterization revealed that the compressional pressure of $80 \mathrm{~mm}$. $\mathrm{Hg}$ used in this study raised intra-abdominal venous pressure to about $20 \mathrm{~mm}$. Hg.

The effective renal plasma flow and glomerular filtration rate were always reduced by increased intra-abdominal pressure, on the average of 24.4 per cent and 27.5 per cent, respectively. The filtration fraction, or the percentage of the plasma flow filtered at the glomerulus, showed no significant change.

It was found that the elevation of renal venous pressure was probably sufficient to account for the reduction of renal plasma flow.

The extraction of sodium $\mathrm{p}$-aminohippurate by the kidney was not altered, indicating the validity of the clearance method for measuring renal plasma flow under these conditions and demonstrating the absence of arteriovenous shunting.

Maximal tubular diodrast excretion (diodrast $\mathrm{Tm}$ ) was reduced significantly in all 5 subjects, while maximal tubular glucose reabsorption (glucose $\mathrm{Tm}$ ) fell significantly in 3 . The percentile decrease in both values was equal to that in effective renal plasma flow and glomerular filtration rate. It appears that this phenomenon cannot be attributed to inadequate loading of tubular transfer mechanisms, as a result of either diffuse or focal ischemia.

The theoretical implications of these findings are discussed. 


\section{ACKNOWLEDGMENTS}

We wish to express our gratitude to the Misses Elizabeth Nolan and Constance Qua for technical assistance.

\section{BIBLIOGRAPHY}

1. Thorington, J. M., and Schmidt, C. F., A study of urinary output and blood-pressure changes resulting in experimental ascites. Am. J. M. Sc., 1923, 165, 880.

2. Swick, M., Intravenous urography by means of the sodium salt of 5-iodo-2-pyridon- $\mathrm{N}$-acetic acid. J. A. M. A., 1930, 95, 1403.

3. Jaches, L., and Swick, M., Opaque media in urology, with special reference to a new compound, sodium ortho-iodohippurate. Radiology, 1934, 23, 216.

4. Carlson, H. E., The proven ineffectiveness of the compression bag in intravenous pyelography. J. Urol., 1946, 56, 609.

5. Wood, E. H., Lambert, E. H., Code, C. F., and Baldes, E. J., Factors involved in the protection afforded by pneumatic anti-blackout suits. N.R.C., C.M.R., C.A.M. Report No. 351, August 24, 1944.

6. Wilkins, R. W., Friedland, C. K., and Bradley, S. E., Estimations of cardiac and vasomotor reserve, especially in response to strains designed to simulate those of acceleration. N.R.C., C.M.R., C.A.M. Report No. 177, September 1, 1943.

7. Goldring, W., Chasis, H., Ranges, H. A., and Smith, H. W., Relations of effective renal blood flow and glomerular filtration to tubular excretory mass in normal man. J. Clin. Invest., 1940, 19, 739.

8. Goldring, W., and Chasis, H., Hypertension and hypertensive disease. The Commonwealth Fund, New York City, 1944.

9. Smith, H. W., Finkelstein, N., Aliminosa, L., Crawford, B., and Graber, M., The renal clearances of substituted hippuric acid derivatives and other aromatic acids in dog and man. J. Clin. Invest., 1945, 24, 388.
10. Fujita, A., and Iwatake, D., Bestimmung des echten Blutzuckers ohne Hefe. Biochem. Ztschr., 1931, $242,43$.

11. Nelson, N., A photometric adaptation of the Somogyi method for the determination of glucose. J. Biol. Chem., 1944, 153, 375.

12. Cournand, A., and Ranges, H. A., Catheterization of the right auricle in man. Proc. Soc. Exper. Biol. \& Med., 1941, 46, 462.

13. Moritz, F., and von Tabora, D., Uber eine Methode, beim Menschen den Druck in oberffächlichen Venen exakt zu bestimmen. Deutsch. Arch. f. Klin. Med., 1910, 98, 475.

14. Wilkins, R. W., and Bradley, S. E., Changes in arterial and venous blood pressure and flow distal to a cuff inflated on the human arm. Am. J. Physiol., $1946,147,260$.

15. Smith, H. W., Physiology of the renal circulation. Harvey Lectures, 1939-1940, Ser. 35, 166.

16. Bradley, S. E., and Bing, R. J., Renal function in the harbor seal (Phoca vitulina L.) during asphyxial ischemia and pyrogenic hyperemia. J. Cell. and Comp. Physiol., 1942, 19, 229.

17. Senator, H., Albuminuria in health and disease. The New Sydenham Society, Selected Monographs, 1884, 110, 1.

18. Smith, H. W., Chasis, H., Goldring, W., and Ranges, H. A., Glomerular dynamics in the normal human kidney. J. Clin. Invest., 1940, 19, 751.

19. Smith, H. W., Lectures on the kidney. Porter Lectures-Series IX. University Extension Division, University of Kansas, Lawrence, Kansas, 1943.

20. Theobald, G. W., The repetition of certain experiments on which Molitor and Pick base their watercentre hypothesis, and the effect of afferent nerve stimuli on water diuresis. J. Physiol., 1934, 81, 243.

21. Wilkins, R. W., Halperin, 'M., and Bradley, S. E., Unpublished data.

22. Bradley, S. E., Studies of hepatic blood flow in man. J. Clin. Invest., 1946, 25, 918. 